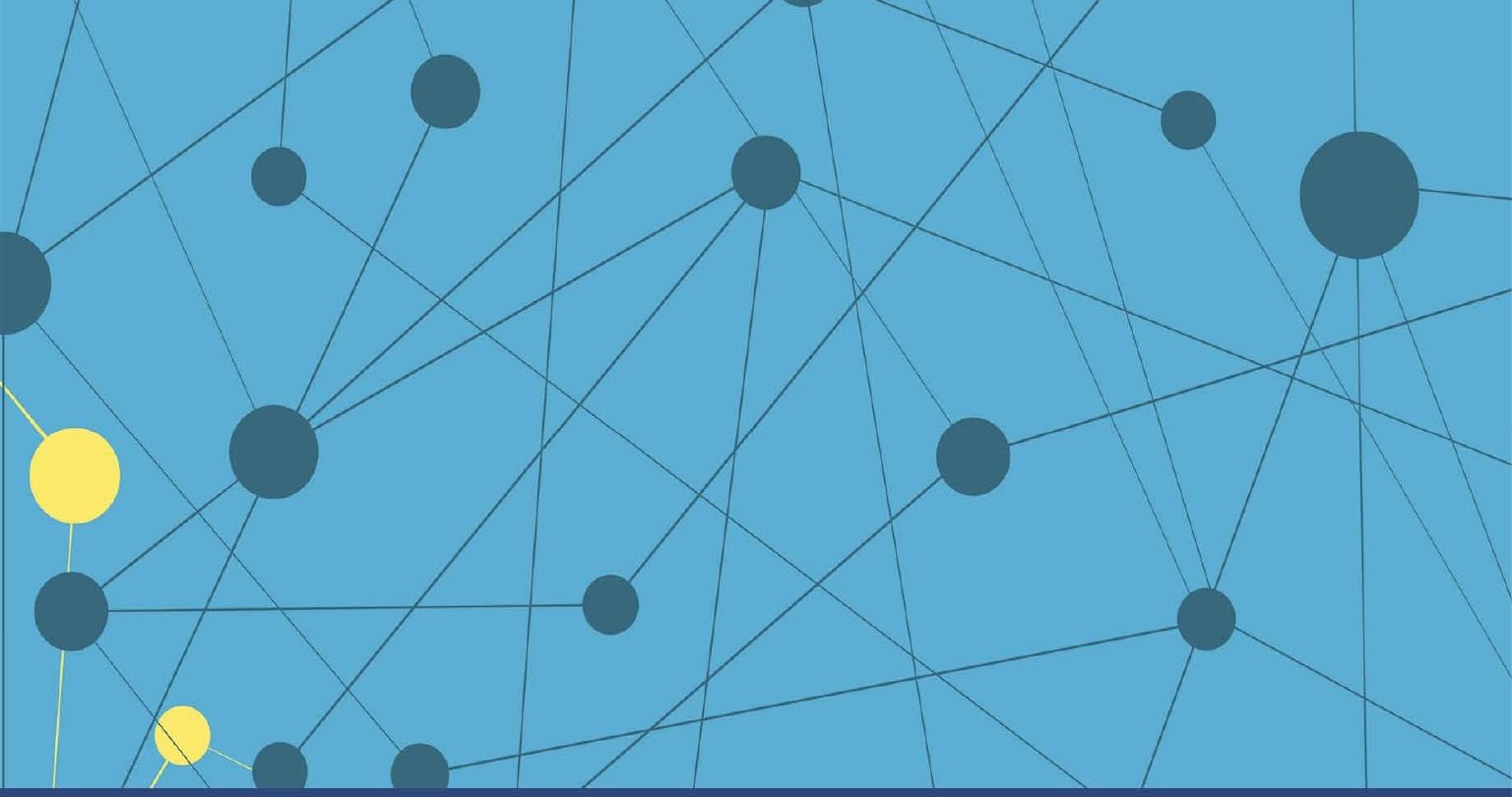

Routledge Contemporary Japan Series

\title{
NEW FRONTIERS IN JAPANESE STUDIES
}

Edited by

Akihiro Ogawa and Philip Seaton 


\section{Contents}

List of figures $\quad \mathrm{x}$

List of tables $\quad$ xi

List of contributors xii

Notes on the text xvi

Acknowledgements xvii

Introduction: envisioning new frontiers in Japanese Studies 1

AKIHIRO OGAWA AND PHILIP SEATON

\section{PART I}

Rethinking Japanese area studies in the twenty-first century

1 Rethinking the Maria $\mathrm{Luz}$ Incident: methodological cosmopolitanism and Meiji Japan

BILL MIHALOPOULOS

2 Exporting theory 'made in Japan': the case of contents tourism

PHILIP SEATON

3 Japanese language education and Japanese Studies as intercultural learning

JUN OHASHI AND HIROKO OHASHI

4 Japanese Studies in China and Sino-Japanese

Relations, 1945-2018

YI ZOU

5 Japanese Studies in Indonesia 


\section{PART II}

Coping with an ageing society

6 Discover tomorrow: Tokyo's 'barrier-free' Olympic legacy and the urban ageing population

DEIRDRE A.L. SNEEP

7 Foreign care workers in ageing Japan: Filipino carers of the elderly in long-term care facilities

KATRINA NAVALLO

8 Immigrants caring for other immigrants: the case of the Kaagapay Oita Filipino Association MELVIN JABAR

PART III

Migration and mobility

9 Invisible migrants from Sakhalin in the 1960s: a new page in Japanese migration studies

S VETLANA PAICHA D Z E

10 Japanese women in Korea in the postwar: between repatriation and returning home MOOAM HYUN

11 Challenging the 'global' in the global periphery: performances and negotiations of academic and personal identities among JET-alumni Japan scholars based in Japan SACHIKO HORIGUCH I

12 Dream vs reality: the lives of Bangladeshi language students in Japan

SIDDIQUR RAHMAN

13 Sending them over the seas: Japanese judges crossing legal boundaries through lived experiences in Australia

STACEY STEELE

14 'Life could not be better since I left Japan!': transnational mobility of Japanese individuals to Europe and the post-Fordist quest for subjective well-being outside Japan 
PART IV

The environment

15 Japan's environmental injustice paradigm and transnational activism

SIMON AVENELL

16 'Community power': renewable energy policy and production in post-Fukushima Japan

A KIHIRO OGA WA

Appendix: survey on Japanese-language education abroad

Index 


\title{
16 'Community power' \\ Renewable energy policy and production in post-Fukushima Japan
}

\author{
Akihiro Ogawa
}

Japan has assumed a central position within global discourses on energy since the catastrophic earthquake and tsunami in 2011 that caused radiation leakage from the Fukushima Daiichi nuclear power plant. This disaster singlehandedly destabilised energy policymaking and production practices in Japan. Before this disaster, many people in Japan, including myself, never gave much thought about energy, and only individuals with some reason to be worried about energy issues engaged in discussion about energy. However, people from a broader cross section of society joined the conversation after the disaster. They started learning about how the electricity system works - how electricity is generated and how it is consumed. Before the 11 March disaster, if and when the general public discussed electricity, it was mostly within the context of global climate change; in other words, how to reduce carbon emissions. Unlike coal and natural gas plants, nuclear energy does not involve carbon emissions during the generation of electricity. Such energy generation reflected an ideal pursuit of development and growth, which dominated our lifestyle over the post-Second World War period. However, the post-disaster landscape reshaped our values and ways of living at the grassroots level. People began to engage in more insightful political debates.

Since the 11 March disaster, I have been looking at opportunities for creating a new energy production infrastructure, built from the bottom up, signalling a shift from the traditional state-centralised, top-down policymaking towards a more decentralised, participatory, self-reliant form of regulation. In particular, I have observed that Fukushima is now a centre for renewable energy production. Stimulated by the efforts of local communities, the drive for renewable energy production at the grassroots level is dynamically expanding further across Japan. What we now require are new paths to renewable and sustainable energy, greater local control over green energy production and more meaningful public participation in the decision-making process to create a greener economy, including more extensive participation from local citizens. Individuals are beginning to experiment with renewable and more efficient modes of energy production. Among the many types of renewable energy, solar power is the easiest to install because the equipment setup is simple. It was also considered profitable because of the relatively high purchase prices when the national government 
first supported solar energy in July 2012 by requiring major electric companies to purchase renewable-derived electricity at set prices.

One important observation is that people I met at field sites referred to such renewable-energy-derived electricity as 'community power' (Iida and ISEP 2014). Community power is defined as renewable energy installations initiated, operated and controlled by local citizens. It is characterised by maximisation of local ownership and decision making, wide distribution of financial benefits and matching energy production to local usage exactly tailored to the community's needs and context. It ensures that local communities have democratic control of renewable energy generation through all stages of planning, installation, operation and distribution through community-owned renewable energy projects. It indeed creates social, economic and political advantages by strengthening local economies, building community resilience and empowerment, and building renewable energy industries, which generates new employment.

This chapter considers the potential for building community power in the post-Fukushima era through an analysis of current examples of Japanese renewable energy production. Japanese citizens had already begun implementing community power industries in the early 2000s, before the Fukushima disaster, following deregulation of the Japanese electricity market. The 11 March disaster further accelerated the national sentiment for community-oriented renewable energy production.

\section{Deregulating Japan's electricity market}

Japan started liberalising its electricity market in the 1990s, when Japan pursued more neoliberal politics that allowed more competition in energy supplies for large-lot factories and corporate customers. This was also in line with the worldwide trend towards deregulation and aimed at correcting Japan's high cost structures and high prices relative to those in other countries (TEPCO 2014). However, the market for households and other small-lot consumers has remained monopolised by regional utilities up to now. Meanwhile, more opportunities have been provided to the renewable energy market. In 2003, the Japanese government enacted a Renewable Portfolio Standard (RPS) scheme, which required electricity retailers to supply a certain amount of renewable electricity to grid consumers. One energy expert reported that the RPS scheme boosted the growth of renewable energy at an annual rate of 8 per cent; and after the introduction of the Excess Electricity Purchasing Scheme for Photovoltaic (or usually simply called 'PV') Electricity, it grew even faster at an annual rate of 13 per cent (Edahiro 2014).

As a result of the Great East Japan Earthquake and the Fukushima Daiichi nuclear power plant accident in March 2011, Japan's electricity market has been radically reviewed. One of the major efforts to deregulate the electricity market was the active introduction of a Feed-in-Tariff (FIT) scheme as the country sought to diversify its energy mix away from nuclear power and bolster its capacity for renewable energy, in particular solar energy. This political sentiment was buoyed by a new policy announced in September 2012 by the ruling Democratic 
Party of Japan (DPJ) government to eliminate nuclear power entirely from Japan's energy mix by 2040, while increasing power supply targets from renewable sources to about 35 per cent (see Eto 2014 for the nationwide discussion process on energy policymaking). However, the September 2012 announcement was totally reversed just three months later (16 December 2012) when the Liberal Democratic Party (LDP) won the majority in the lower house election and Shinzo Abe, a hawkish politician, returned as prime minister.

The FIT scheme mandates power companies to buy electricity generated by renewable sources at fixed prices set by the government, on the assumption that the prospect of stable revenues would facilitate investment in renewable power generation. In the process of liberalising the electricity market, Japan had already enacted a FIT scheme in November 2009 that required utilities to purchase excess solar power sent to the grid by homes and businesses and pay twice the standard electricity rate for that power. Meanwhile, the pre-quake Strategic Energy Plan announced by the DPJ in 2010 emphasised nuclear power as the mainstay of Japan's energy supply and offered little guidance for addressing renewable energy (Hiranuma 2014). In 2010, the year before the Fukushima disaster happened, nuclear power accounted for 28.6 per cent of Japan's total power generation and renewable energy for only 1.1 per cent (METI 2014).

The new FIT scheme was introduced by the DPJ government in July 2012 with a rate of 42 yen (US 38 cents) per kWh (excluding taxes) for solar power over a period of 20 years. Since then, the number of renewable energy businesses, mainly photovoltaic power producers, has grown across the country. The rate was indeed extremely generous and triggered a surge in solar investment. The tariffs are among the highest (some even say unnecessarily high) in the world. Japan became the largest solar photovoltaic market in the world, replacing Germany in 2013, according to Bloomberg News (4 June 2013). This is a result of investments in response to government incentives developed after the Fukushima nuclear crisis to encourage green energy. Following the announcement of the tariffs, we observed almost daily declarations that renewable industry players would plan to open operations. In particular, solar power plants could be built relatively easily and quickly, from small residential rooftop projects with a capacity up to $10 \mathrm{~kW}$ to large mega solar photovoltaic power plants with an output of several megawatts. The Japan Times (31 October 2015) reported that solar output during the peak-demand period in the summer of 2014 reached 6.33 million $\mathrm{kW}$ - the equivalent of six nuclear reactors.

In April 2013, the Japanese cabinet of Prime Minister Abe decided on a 'Policy on Electricity System Reform' consisting of three main steps to secure a stable national power grid by breaking the monopolies of the ten electric power companies: (1) expanded operation of wide-area electrical grids by 2015; (2) full liberalisation of the retail market and power generation by 2016; and (3) legal structural separation, including the unbundling of the generation and transmission of electricity into operations run by separate companies by 2020 .

The first stage of the process commenced in 2015, establishing an independent regulator: the Organization for Cross-regional Coordination of Transmission 
Operators (Denryoku köikiteki un'ei suishin kikan). This was created to overcome a concern that an electricity generator would still be able to own distribution through a holding company structure. Then, by April 2016, Japan's electricity market was fully deregulated by opening up the remaining retail electricity market, which included residential and small business consumers. With the large number of new market players as renewable energy generators, Japan is now preparing to finally end the long-standing monopoly of the ten regional electric power companies, which will likely lose some of their market share to newcomers. In 2020, furthermore, the national government plans to separate the power transmission business from the power production business, which will be expected to create another space for newcomers, although there is still an unfavourable development in that the big electric companies are creating sister companies to run the grid. Therefore, electricity will still be in the control of the same big companies and continue to be difficult for other producers to use. They are protecting the stability of the grid, so newcomers can only connect a maximum voltage of $50 \mathrm{~kW}$ on to the network (as of 15 July 2018). Surviving with such vested interests along with other renewable energy generators, 'community power' entities are gaining momentum.

\section{Stories from Fukushima}

Iitate in Fukushima Prefecture has experienced a huge tragedy. Before 11 March, it was a quiet traditional village where people enjoyed rural life. Three, or even four, generations of the same family lived together under one roof, practising agriculture and dairy farming. Indeed, Iitate is a well-known farming region in Fukushima for wagyu cattle. At one time, the village was listed as the twelfth most beautiful village in Japan. Iitate is also an archaeologically important site that people began inhabiting thousands of years ago, prompting a regular exhibition of Iitate life at the Fukushima Prefectural Museum in Aizu Wakamatsu. People lived in harmony with nature, surrounded by thick forests. Their life was simple and quiet, and residents believed that their lives would continue in this way forever.

Their lives were completely destroyed by the explosion of the Fukushima Daiichi nuclear power plant, $40 \mathrm{~km}$ southeast of the village. The residents of Iitate were informed that they were safe as their homes were outside the $20 \mathrm{~km}$ (12 miles) evacuation zone designated by the national government on 12 March, and so they stayed. The earthquake itself did not significantly affect village life. However, 20 days later, on 30 March, the International Atomic Energy Agency informed them that they exceeded the operational criteria for evacuation in terms of radiation exposure. This was primarily because of wind patterns, as Iitate was directly in the path of a radiation plume. Massive amounts of radioactive particles were deposited by precipitation on the night of 15 March. Following the announcement, the government ordered the evacuation of all litate residents by 11 April. Because residents were not fully informed, all 6000 Iitate residents were exposed to harmful levels of radiation. One report gave a reading outside the village office on the evening of 15 March of a startling $44.7 \mu \mathrm{Sv} / \mathrm{h}$, an 
extraordinarily high level of radiation (Fukushima Prefecture 2011). The Japanese government-set target is $0.23 \mu \mathrm{Sv} / \mathrm{h}$. The residents of Iitate were eventually forced to leave the village, leaving everything behind. Many families were split up, with members of the three generations living in different locations.

I visited the Iitate Village Office in August 2015 as part of a group of researchers organised by a local journalist. I observed the presence of Office employees, and I assumed that they were already preparing for the return of the residents, although the evacuation order would not be lifted until 31 March 2017, more than one-and-a-half years later. Iitate was the first local authority in Fukushima Prefecture to set a date for ending the evacuation, in 2012, when the mayor, Mr Norio Kanno, promised to reboot the village within five years. In June 2015, two months before my visit, decontamination work was completed in the village's residential areas, and the cost of decontamination had reached approximately 200 million yen (1.8 million US\$) per household. Reports suggested that the work had reduced the average radiation level in the air to $0.8 \mu \mathrm{Sv} / \mathrm{h}$. Meanwhile, my radiation survey meter outside read $0.46 \mu \mathrm{Sv} / \mathrm{h}$. The internationally accepted level for radiation absorption is $1 \mathrm{mSv} / \mathrm{h}$ or less per year, although the International Atomic Energy Agency and others suggest that, for the case of Fukushima, anything up to $20 \mathrm{mSv}$ or less per year (the typical worldwide limit for workers in nuclear plants) poses no immediate danger to human health: $0.8 \mu \mathrm{Sv} / \mathrm{h}$ translates to $7.012 \mathrm{mSv} / \mathrm{h}$.

Shortly after emerging from the car, I tasted metal in my mouth, a common experience for people with no prior radiation exposure. On the drive, I saw many black plastic bags piled up like mountains. They were dampened bags containing irradiated soil, leaves and debris from the decontamination operation. The dampened piles of bags were everywhere in this village, which made me think that ordinary peaceful life would never return here. In the village, meanwhile, I saw many solar panels installed at unused farmland sites. The local journalist told us that people in Iitate are trying to expand the solar panel industry on farmland because, even if agricultural products are grown, it is unlikely that people will purchase them given public concern about radiation. At that time, I was informed that the solar panels I saw in a place called Itamizawa were set up by the Iitate Electric Power Co., a community-oriented renewable energy firm.

After the trip to Iitate, I scheduled a follow-up interview with Mr Norimichi Chiba, managing director of the Iitate Electric Power Co., and visited the company's office in Fukushima City. The headquarters are in Iitate; however, due to the evacuation, the office is temporarily housed in a building in the centre of Fukushima City. Chiba, a retiree in his early 60s, told me that the company was established in September 2014 by Mr Minoru Kobayashi, who was born and raised in Iitate. Kobayashi's family had been running a farm there, planting rice and breeding prized Japanese black wagyu Iitate Gyu. Soon after the 11 March disaster, he evacuated his cattle to a friend's ranch in Zaō, a town in the neighbouring Miyagi Prefecture, and continued breeding cattle. Since then, Kobayashi had been commuting to Zaō from his evacuation home in Kitakata, a city in the Aizu region, northwest Fukushima, to take care of his cattle. 
During the conversation, I asked Chiba directly about his motivations for starting their renewable energy business. Chiba mentioned that he and Kobayashi were heavily influenced by Mr Yauemon Sato, whose name I already knew because it had been mentioned by many people involved in the renewable energy business. After the 11 March disaster, Sato set up his own renewable energy firm in August 2013: Aizu Denryoku (Aizu Electric Power Co.) in Kitakata, to where Kobayashi evacuated. Sato was the representative partner of Yamatogawa Sake Brewery, a local brewery established in 1790 in Kitakata City.

Sato was an influential advocate of renewable energy. He had no background in electricity production, but using his business experience of getting small breweries into markets dominated by larger manufacturers, he established the Aizu Electric Power Co. in August 2013 with local friends, municipalities and business associates. With a capital of 38 million yen (350,000 US\$), the company built 48 solar power plants. As of July 2016, his company had produced a total of 3,877 kW (Aizu Electric Power Co. 2016) and sold the electricity to Tohoku Electric Power Co. All the solar plants are relatively small scale, as the company intends to create sustainable employment in local communities. Those plants also disperse risk within electricity generation. His renewable energy business has been expanding to include hydraulic and biomass energy. To expand the business, the company further raised 100 million yen $(900,000$ US\$) through fund raising at 200,000 yen (1800 US\$) per unit by consumers in the Tokyo metropolitan area to support Fukushima residents (Sato 2017, p. 44).

Sato is a so-called 'hero social entrepreneur' who 'has received a disproportionate amount of foundation and media attention' (Nicholls 2011, p. 87). In a feature article on him in Asahi Shimbun (18 April 2015), he remarked:

I thought when the nuclear plants exploded, my business for the past 200 years would be over.... Nothing would be gained by blaming the state and TEPCO. What caught my attention were many power plants in Aizu where plenty of water was available....

What we need to survive are water, food, and energy. We have plenty of water, food, and energy. Electricity generated by hydraulic power plants in Aizu is ten times more than the amount required by the entire Fukushima prefecture. There is an enormous potential for renewables in Fukushima.

'Community independence with an energy revolution' is an important corporate mission, according to his company leaflet. TEPCO indeed deprived them of the capability to produce electricity in Fukushima. Fukushima was like a domestic colony of the Tokyo metropolitan area and sent electricity to the capital without consuming it locally at all.

I attended a national symposium on renewable energy in November 2017 at which Sato was a speaker. He explained his company's missions to the audience, who were mostly conscientious citizens interested in establishing renewable energy businesses: 
If a big company is coming from outside of Fukushima, the money earned will be moving out from Fukushima. This would be the same structure adopted by TEPCO. We need to change this structure or circulate our money within the local area.... But instead of just complaining, we are responsible for overlooking the nuclear power plants. Instead of bringing energy sources from outside, we will take advantage of renewable sources, including solar, hydro, biomass, geothermal, and wind.... Through these activities, our children will understand that 'we can change our society by ourselves'. I want to hand over such a community to the next generation.

Utilising local money and resources, Aizu Electric Power Co. envisions a sustainable society. Ultimately, Sato intends to re-gain by buying back the water rights for electricity generation in Lake Inawashiro, the fourth largest lake in Japan, which TEPCO and Tohoku Electric Power Co. have now monopolised (see Asahi Shimbun, 18 April 2015). The Aizu Basin is the bread basket of Fukushima Prefecture. It has long been blessed with not only natural resources but also many local historical and cultural treasures. By having plenty of natural resources, people can enjoy a self-sufficient life, or produce locally and consume locally.

Influenced by Sato, Kobayashi decided to create a renewable energy company. Both Kobayashi and Chiba of the Iitate Electric Power Co. were well connected within Sato's renewable energy network. Kobayashi raised over 10 million yen $(90,000$ US\$) in funds for renewable energy production from local people and businesses. Chiba helped set up Iitate Electric Power Co. As an engineer by training and career, he had already gained some experience in the renewable energy industry at a geothermal energy power site in Tsuchiyu, an onsen (hot-spring) town in Fukushima that suffered a sharp decrease in tourists after the 11 March disaster. People there incorporated renewable energy business practices into the reconstruction plans, which combined revitalisation of the community with job creation. They worked on binary geothermal power with good quality and high temperature and pressure water. Chiba was one of the key figures in the geothermal project. He said to me: 'Renewable energy should be something citizens can be in charge of.' In fact, Iitate Electric Power Co. is supported by villagers' investments and donations. The firm asked for villagers' permission to install solar panels on their farmland. As of July 2016, when I interviewed him, I was told that 35 villagers had installed 30 solar panels of $50 \mathrm{~kW}$ each. The firm then sold the electricity generated at 27 yen per $\mathrm{kWh}$ (US 25 cents) to the Tohoku Electric Power Co. and can continue doing so under the FIT scheme for the next 20 years. Some of the earnings were used to pay the investors or villagers as rent for using their land.

What I found interesting about post-Fukushima Japan is that renewable energy policy and production provides an active window into the political processes in which multiple actors work to consolidate a new rationale of postnuclear energy and connect production activities involving renewable energy. Good examples are the Japanese movements promoting renewable energy at the 
grassroots level that were established in the wake of the Fukushima Daiichi nuclear disaster. One such movement is called Zenkoku gotōchi enerugi kyōgikai (http://communitypower.jp/), or the Japan Community Power Association, which is an emerging networking entity of energy-focused social enterprises and concerned individuals who promote and produce renewable energy in Japan. Originally, it was established as the 'Community Power Initiative' in June 2013, and then reorganised as Japan Community Power Association in May 2014. Sato, the founder of the Aizu Electric Power Co., is the board chair of the Japan Community Power Association. The network creates an anonymous citizen investment fund centred in communities and implemented by renewable energy businesses. As of January 2019, 51 citizen-based community-oriented renewable energy-related businesses and their supporters across the country organised a platform or 'alliance' for renewable energy generation, which includes Aizu Electric Power Co., Iitate Electric Power Co. and others. This emerging network, the Japan Community Power Association, presents both the classical Tocquevillian attitude, focusing on advocacy through representative democracy, and a design for public services in accordance with the values of concerned citizens. It also provides valuable guidance for agencies concerned with developing and nurturing green energy social enterprises.

\section{Ways of living sustainably}

Energy is central to nearly every major challenge and opportunity the world faces today. Be it for jobs, security, climate change, food production or increasing incomes, access to energy is essential for all. Sustainable energy is an opportunity - it transforms lives, economies and the planet. In 2015, we observed two important international agreements developed to support the 'community power' movements I have argued for thus far: the United Nation's Sustainable Development Goals (SDGs) (United Nations Sustainable Development 2015) and the Paris Agreement on climate change (United Nations Framework Convention on Climate Change 2015). These policy developments helped buoy the current positive sentiment towards renewable energy production globally.

SDGs form the core of the 2030 Agenda for sustainable development titled 'Transforming Our World: The 2030 Agenda'. It balances the economic, social and ecological dimensions of sustainable development, and places sustainable development and the fight against poverty on the same agenda for the first time. One of the SDGs mentions energy. Access to energy is an essential prerequisite to achieving many sustainable development goals. In particular, it targets to ensure access to affordable, reliable, sustainable and modern energy for all by 2030; more specifically, Goal 7 aims for a substantial increase in the share of renewables in the global energy mix and a doubling in the global rate of improvement in energy efficiency. Another target is to promote research in renewable energy and energy efficiency, as well as investment in energy infrastructure and clean energy technologies. Furthermore, the Paris Agreement on climate change, which came into force in 2016, addressed the need to limit the 
rise of global temperatures. This is a historic agreement to combat climate change and unleash actions and investment towards a low carbon, resilient and sustainable future. The main aim of the universal agreement is to maintain the global temperature rise in this century well below $2^{\circ} \mathrm{C}$ and to drive efforts to limit the temperature increase even further to $1.5^{\circ} \mathrm{C}$ above pre-industrial levels. Renewable energy is an essential part of the solution to climate change. According to the United Nations,

Affordable, scalable solutions are now available to enable countries to leapfrog to cleaner, more resilient economies. The pace of change is quickening as more people are turning to renewable energy and a range of other measures that will reduce emissions and increase adaptation efforts.

(United Nations Sustainable Development 2015)

These global policy developments were supported by a comment by Fatih Birol, Executive Director of the International Energy Agency (IEA): 'We are witnessing a transformation of global power market led by renewables' (BBC 2016). The comment was made in October 2016, when the IEA released a report (IEA 2016a) that renewables have surpassed coal to become the largest source of installed power capacity in the world; in 2015, renewables accounted for more than half of the increase in power capacity, and about half a million solar panels were installed every day around the world. In fact, 2015 marked a turning point for renewable energy. Renewable energy represented more than half the new power capacity around the world, reaching a record $153 \mathrm{GW}, 15$ per cent more than the previous year. Furthermore, most of these gains were driven by recordlevel wind additions of $66 \mathrm{GW}$ and solar PV additions of $49 \mathrm{GW}$. According to the IEA (2016b), there are many factors behind this remarkable achievement: more competition, enhanced policy support in key markets and technology improvements. While climate change mitigation is a powerful driver for renewables, it is not the only one. In many countries, combating deadly air pollution and diversifying energy supplies to improve energy security play an equally strong role in growing low-carbon energy sources, especially in Asia. It forecasts that renewables will remain the fastest-growing source of electricity generation, with their share growing to 28 per cent in 2021 from 23 per cent in 2015.

All of the dynamism, both at the grassroots level and as part of policymaking, exploring alternative energy policies and practices can be classified in the context of 'natural capitalism' (Hawken 1997; Hawken, Lovins and Lovins 1999). Natural capitalism is industrial capitalism reformed to incorporate the value of 'natural capital', or life-supporting systems and resources. Ancillary tenets include reducing waste, increasing efficiency, mimicking natural systems and transitioning to a flow and service economy. Paul Hawken (1997) observes, 'Natural capitalism is not making sudden changes, uprooting institutions, or fomenting upheaval for a new social order... Natural capitalism is about making small, critical choices that can tip economic and social factors in positive ways.' Through the generation of community power under natural capitalism, 'creating 
synergies', as termed by Ostrom (1996, p. 1082), are generated in the society. Ostrom reflects, 'when co-productive inputs are diverse entities and complements, synergy can occur... [Participants] build a credible commitment to one another so that if one side increases input, the other will continue at the same or higher levels.'

Governments, businesses and civil society together with the United Nations are mobilising efforts to achieve the United Nations SDGs as well as the Paris climate accord. In contemporary Japan, the ongoing deregulation of electricity production and distribution is a political agenda; deregulation increases the choice of power companies for ordinary citizens, under the assumption that competition between electrical service providers will result in better services and more innovation, in response to consumer needs.

In July 2018, the Japanese government announced a medium- to long-term energy plan - a national guideline for energy policy (Japanese Cabinet Office 2018) - that envisions a shift towards renewable energy and cuts dependence on fossil fuels and nuclear power. The basic energy plan, which is updated once every three to four years, showed that the government aims to have renewables account for 22 to 24 per cent, fossil fuels 56 per cent and nuclear power 20 to 22 per cent of the country's electricity generation by 2030, despite criticism from civil society. Green Peace Japan, an international environmental NGO, claims, 'It lacks urgent and ambitious renewable energy targets, while maintaining dangerously high coal targets, and unrealistic targets for the troubled nuclear sector' (Greenpeace Japan 2018). However, I would say that changes will be incremental. The most recent data available for the share of renewable energy in Japan were 14.5 per cent (which includes hydro 7.6 per cent), along with thermal power 83.8 per cent and nuclear power 1.7 per cent (Agency for Natural Resources and Energy 2016). The share for renewable energy is almost the same level as France (16.3 per cent) and the United States (13.6 per cent) (IEA 2017). The increased focus on renewables under the United Nation's SDGs and the Paris climate accord underscores Japan's challenge to reduce greenhouse gas emissions in the years ahead.

Consumers, innovative entrepreneurs, active citizens, local people and communities, and governments are forming a platform for community power. They are developing and accumulating ecological knowledge and technology to create a sustainable greener economy by practising 'natural capitalism' in their daily lives. Expanding renewable, sustainable energy, or what I called community power in this chapter, could contribute to natural capitalism, and also, importantly, could further the development of local participative democracy when various approaches to the concept succeed in simultaneously realising a substantial increase in citizen involvement and more efficient governance. Community power is indeed changing the existing partnership between state authorities and citizens. The new partnership empowers citizens to contribute more of their own resources. Citizens are regarded as co-producers of public services, instead of simple consumers, as argued in the new public management scholarship (Bovaird 2007). 
Globally, the green energy industry has reached a new stage in its development. Some renewable technologies have become more affordable, particularly in developed markets, making them cost competitive with fossil fuels. Now, the focus is on the challenges ahead in promoting these renewable technologies in the face of opposition to this shift, and identifying institutional frameworks, including the FIT system, required to make green energy more attractive. Today, an awakened global consciousness is heralding the active shift away from conventional energy practices towards the use of green energy worldwide. Community power innovation has become mainstream, and this chapter has documented the long-term effects of these new values, practices, relationships and institutions as they relate to the construction of a green economy and increased alternative energy consumption.

\section{References}

Agency for Natural Resources and Energy, 2016. Sōgō energui tōkei 2016 (Comprehensive statistics on energy in 2016). Tokyo: Agency for Natural Resources and Energy.

Aizu Electric Power Co., 2016. Kaisha an'nai (Company profile). Aizu Wakamatsu: Aizu Electric Power Co.

Asahi Shimbun, 2015. Front runner: denki no jikyūde fukushimano jiritsu wo (Making Fukushima independent by achieving energy self-sufficiency) [online]. Asahi Shimbun, 18 April. Available from: www.asahi.com/articles/DA3S11707539.html [accessed 10 November 2019].

$\mathrm{BBC}, 2016$. Renewable energy capacity overtakes coal [online]. BBC, 26 October. Available from: www.bbc.com/news/business-37767250 [accessed 30 January 2019].

Bloomberg News, 2013. Japan set to overtake Germany as world's largest solar market [online]. Bloomberg News, 4 June. Available from: www.bloomberg.com/news/ articles/2013-06-04/japan-set-to-overtake-germany-as-world-s-largest-solar-market [accessed 15 July 2018].

Bovaird, T., 2007. Beyond engagement and participation: user and community coproduction of services. Public Administration Review, 67(5), 846-860.

Edahiro, J., 2014. Renewable energy in Japan: current trends show promise and opportunities [online]. Available from: www.ecology.com/2014/01/07/renewable-energy-injapan-current/ [accessed 30 January 2019].

Eto, M., 2014. Diverse voices and democratic policymaking: lessons from the national debates on post-Fukushima nuclear policy in Japan. Paper presented at the Australian Political Studies Association Conference, 29 September.

Fukushima Prefecture, 2011. 20 30 kiro ken fukin kankyō hōshanō sokutei kekka (Measurements of environmental radiation in the areas of 20-30 kilometres) [online]. Fukushima Prefecture. Available from: www.pref.fukushima.jp/j/20-30km18.pdf [accessed 30 January 2019].

Greenpeace Japan, 2018. Japan new energy plan a 'missed opportunity' for stronger climate action [online]. Greenpeace Japan, 3 July. Available from: http://m.greenpeace. org/japan/ja/high/news/press/2018/pr201807031/ [accessed 30 January 2019].

Hawken, P., 1997. Natural capitalism [online]. Mother Jones May/Apr 97. Available from: www.mindfully.org/Sustainability/Hawken-Natural-Capitalism.htm [accessed 30 January 2019]. 


\section{Akihiro Ogawa}

Hawken, P., Lovins, A. and Lovins, L.H., 1999. Natural capitalism. London: Earthscan.

Hiranuma, H., 2014. Japan's energy policy in a post-3/11 world: juggling safety, sustainability and economics [online]. The Tokyo Foundation - Articles. Available from: www.tokyofoundation.org/en/articles/2014/energy-policy-in-post-3-11-world [accessed 16 December 2015].

IEA, 2016a. Medium-term renewable energy report. Paris: IEA.

IEA, 2016b. IEA raises its five-year renewable growth forecast as 2015 marks record year. Paris: IEA.

IEA, 2017. Energy balances of OECD countries. Paris: IEA.

Iida, T. and ISEP, 2014. Community power, enerugi de chiiki wo yutakani suru (Community power, enriching community by energy). Tokyo: Gakugei shuppansha.

Japanese Cabinet Office, 2018. Dai 5 ji Enerugi kihon keikaku (The fifth energy basic plan). Tokyo: Cabinet Office.

Japan Times, 2015. Editorial: review of feed-in tariff system. Japan Times, 31 October. Available from: www.japantimes.co.jp/opinion/2015/10/31/editorials/review-feed-tariffsystem/\#.XceA8L9S_7k [accessed 10 November 2019].

METI, 2014. Enerugi hakusho 2014 (White paper on energy 2014). Tokyo: METI.

Nicholls, A., 2011. Social enterprise and social entrepreneurs. In: M. Edward, ed. The Oxford handbook of civil society. Oxford: Oxford University Press, 80-92.

Ostrom, E., 1996. Crossing the great divide: co-production, synergy and development. World Development, 24(6), 1073-1087.

Sato, Y., 2017. Shizen enerugi de jiritubunsan nettowaku gata shakai wo tsukuru (Heading towards a regional independence with an energy revolution). Kikan Keizai Riron, 54(1), 43-45. Edited and translated by Yasuo Goto.

TEPCO, 2014. Liberalization of the electric power market [online]. TEPCO. Available from: www.tepco.co.jp/en/corpinfo/ir/kojin/jiyuka-e.html [accessed 30 January 2019].

United Nations Sustainable Development, 2015. 17 Goals to transform our world [online]. United Nations. Available from: https://sustainabledevelopment.un.org [accessed 30 January 2019].

United Nations Framework Convention on Climate Change, 2015. Historic Paris agreement on climate change: 195 nations set path to keep temperature rise well below 2 degrees Celsius [online]. UNFCCC. Available from: https://unfccc.int/news/finale-cop21 [accessed 30 January 2019]. 


\section{University Library}

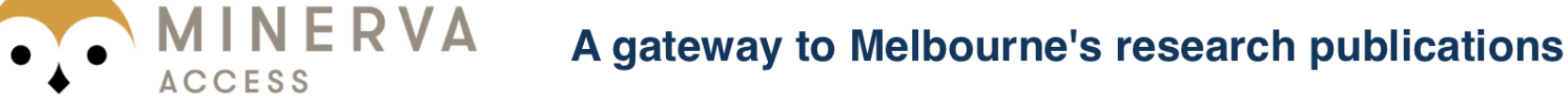

Minerva Access is the Institutional Repository of The University of Melbourne

\section{Author/s:}

Ogawa, A

Title:

'Community power': Renewable energy policy and production in post-Fukushima Japan

Date:

2020

\section{Citation:}

Ogawa, A. (2020). 'Community power': Renewable energy policy and production in postFukushima Japan. Ogawa, A (Ed.). Seaton, P (Ed.). New frontiers in Japanese studies, (1), pp.221-232. Routledge - Taylor \& Francis.

Persistent Link:

http://hdl.handle.net/11343/258615

License:

CC BY-NC-ND 